\title{
Brazing of Zirconia to Titanium using Ag-Cu and Au-Ni Filler Alloys
}

\section{(Brasagem da Zircônia ao Titânio usando Ligas de Adição Ag-Cu e Au-Ni)}

\author{
Jean S. Pimental, Augusto J. A. Buschinelli², Rubens M. do Nascimento 3 , \\ Augusto E. Martinelli ${ }^{3}$, Joseph Remmel ${ }^{4}$ \\ ${ }^{1}$ Federal Institute of Santa Catarina - Campus of Xanxere, Xanxere-SC, Brazil, \\ jean.pimenta@ifsc.edu.br \\ ${ }^{2}$ Federal University of Santa Catarina, Department of Mechanical Engineering/Labsolda, \\ Florianopolis-SC, Brazil \\ ${ }^{3}$ Federal University of Rio Grande do Norte, Department of Materials Engineering, Natal-RN, Brazil \\ ${ }^{4}$ Forschungszentrum Juelich, Zentralabteilung Technologie - ZAT, D 52425 Juelich, Germany
}

\begin{abstract}
Advanced ceramic is usually joined to metal by the well-known direct brazing process, where costly active filler alloys can be considered a limitation. Brazing using active-metal-free filler alloy as insert between the joint components is an attempt to overcome it. The active metal diffusion from the titanium member through the bulk of molten filler to the ceramic was responsible to produce an active filler alloy in loco and promote reduction of the zirconium oxide to improve wetting on the ceramic surface. Unalloyed titanium was joined in a high-vacuum furnace $\left(<3 \times 10^{-5}\right.$ mbar) to yttria-tetragonal zirconia polycristals $(Y-T Z P)$ and zirconia partially stabilized with magnesia (Mg-PSZ), where commercial fillers Ag-28Cu and Au-18Ni with respective thermal cycles were evaluated. Helium gas leak detection test was performed at the ceramic/metal interface at room temperature; samples from reliable vacuum tight joints were examined by microstructural analysis techniques and energy dispersive X-ray analysis at the joint cross-section. Tight joints were produced with eutectic Ag-Cu filler, revealing an intermetallic layer and a dark reaction layer near the ceramic surface; titanium diffusion was efficient for superficial chemical interactions between individual components. Brazing joints were also tested using three-point flexure testing.
\end{abstract}

Key-words: Brazing; Zirconia; Titanium; Ceramic/metal joining.

Resumo: Uma cerâmica avançada é geralmente unida ao metal pelo processo de brasagem, porém o custo das ligas de adição ativas pode ser considerado uma limitação. A brasagem com uma liga de adição isenta de metal ativo para união dos componentes é uma tentativa de transpor esta desvantagem. A difusão de um metal ativo a partir do componente de titânio através do liga de adição fundida para o componente cerâmico produziu uma liga ativa in loco, promovendo a redução do óxido de zircônio e melhorando o molhamento na superfície cerâmica. Titânio não ligado foi unido a zircônia tetragonal (Y-TZP) e zircônia parcialmente estabilizada com magnésia (Mg-PSZ) em forno de alto vácuo $\left(<3 \times 10^{-5} \mathrm{mbar}\right)$, usando ligas comerciais Ag-28Cu e Au-18Ni. Testes de detecção de vazamento de gás hélio foram realizados na interface cerâmica/metal à temperatura ambiente; amostras de juntas estanques foram analisadas por técnicas de análise microestrutural e análise por dispersão de raios-X na seção de união das juntas. Juntas estanques foram produzidas com a liga eutética Ag-Cu, formando-se uma camada intermetálica e uma camada escura de reação próxima à superfície cerâmica; a difusão de titânio foi eficiente para promover interações químicas entre os componentes. As juntas brasadas também foram ensaiadas com teste de flexão três-pontos.

Palavras-chave: Brasagem; Zircônia; Titânio; União cerâmica/metal.

\section{Introduction}

Advanced ceramics are actually increasingly important as engineering materials either as structural or electrical materials for electronic devices. Ceramics are both expensive and difficult to fabricate into large or complex shaped components.

Recebido em 06/08/2013, texto final em 08/10/2013.
To overcome these disadvantages, their technical application strongly depends on the reliability of joining techniques especially with metals or metal alloys to produce new hybrid components.

Zirconia ceramic exhibits three well-defined polymorphs at atmospheric pressure: monoclinic $\left(\mathrm{m}-\mathrm{ZrO}_{2}\right)$ at room temperature; tetragonal $\left(\mathrm{t}-\mathrm{ZrO}_{2}\right)$ with increasing temperature above $\approx 1170^{\circ} \mathrm{C}$; and then cubic structure $\left(\mathrm{c}-\mathrm{ZrO}_{2}\right)$, starting at about $2360^{\circ} \mathrm{C}$, with melting temperature by $2716^{\circ} \mathrm{C}[1,2]$. A suitable tetragonalmonoclinic $(\mathrm{t} \rightarrow \mathrm{m})$ transformation is important to promote high abrasion strength associated to better mechanical properties. 
Additions of specific metal oxides such as calcia $(\mathrm{CaO})$, magnesia (MgO) or yttria (usually 3.0-4.5 mol\% or equivalent $\approx 6-8 \mathrm{wt} . \%$ $\mathrm{Y}_{2} \mathrm{O}_{3}$ ) and controlled heat treatment are crucial to overcome the increased volume (3-5\%) typical of pure zirconia caused by $t$ $\rightarrow \mathrm{m}$ transformation, which is similar to martensite formation when steel is quenched $[1,3,4]$. Induced stresses are sufficient to produce spontaneous cracking in pure zirconia under cooling from its firing temperature. High corrosion strength at elevated temperatures and higher mechanical strength and fracture toughness compared to other dense ceramics are important properties in a large technical application, ranging from cutting and machining tools, gas turbines to oxygen sensors and solid oxide fuel cells [5-7].

Joining zirconia to titanium or titanium alloys shows attractive features to produce potential joints due to mutual structural/ aerospace and biomedical applications; and their linear thermal expansion coefficients $(\alpha-\mathrm{CTE})$ are closely matched, which is crucial to accommodate residual stresses produced at the joint interface $[1,8]$. For instance, partially stabilized zirconia (PSZ) and unalloyed titanium (ASTM Grade 4, annealed) have similar $\alpha$-CTE values $\left(\approx 10 \times 10^{-6 /}{ }^{\circ} \mathrm{C}\right.$ and $\approx 11 \times 10^{-6} /{ }^{\circ} \mathrm{C}$ respectively) [9].

Techniques available to fabricate reliable ceramic/metal joints for structural applications have been studied and attention has been given to parameters of both direct and indirect bonding using liquid- and solid-phase materials. Active metal brazing and diffusion bonding have been continuously investigated for joining ceramics either to themselves or to metals because these techniques provide good strength and heat resistance [8,10-12].

Brazing is a flexible one-step process that has been a good technological solution for joining dissimilar materials using filler alloys containing active metals such as $\mathrm{Ta}, \mathrm{Nb}, \mathrm{Zr}, \mathrm{V}$ or especially $\mathrm{Ti}[1,5,6,9]$. The role of an active metal is to reduce the main oxide of the ceramic composition and promote wetting on the ceramic surface by the molten filler alloy to obtain sound chemical bonding with the metallic member. Moreover, the presence of an active metal with thermodynamic affinity for oxygen is crucial. However, excessive reduction reactions can produce a reaction layer with undesirable intermetallic phases, reducing mechanical properties of the brazing joint [13]. The higher costs of active fillers combined to the limited concentration of active metals in their composition have led to alternative joining approaches, such as previous metallization of the ceramic surface with an active metal and subsequent indirect brazing process $[14,15]$.

Several techniques for ceramic metallization have been reported, such as plasma spray, physical and chemical vapor deposition (PVD and CVD process) and electrochemical deposition $[13,16]$. Furthermore, the well-known Mo-Mn process is inappropriate for zirconia metallization because it does not have a glassy intergranular phase, which is a key factor for successful bonding between metal and the ceramic substrate $[1,10]$. Nevertheless, the techniques previously mentioned have the limitation of being more expensive and laborious than active metal brazing.

This study was aimed at the joining of zirconia to unalloyed titanium using an experimental method based on brazing process. Active-metal-free filler alloys were tested as inserts between dissimilar contact surfaces to minimize residual stresses during post-fabrication cooling due to eventual $\alpha$-CTE mismatch of the couple. Moreover, the active metal responsible for the superficial reducing of zirconia ceramic was properly supplied by Ti diffusion from the metallic member to the ceramic surface. Characterization of the microstructure at the resultant interface and evaluation of the mechanical strength by three-point bend testing were also performed.

\section{Experimental Procedures}

Ceramic rods of $\varnothing 8.0 \mathrm{~mm}$ of yttria-tetragonal zirconia polycristals ( $\mathrm{Y}-\mathrm{TZP}, \approx 5 \% \mathrm{Y}_{2} \mathrm{O}_{3}, \%$ wt.) and zirconia partially stabilized with $\mathrm{MgO}$ (Mg-PSZ, $\approx 4 \% \mathrm{MgO}, \%$ wt.) were supplied by Engecer Ltda. (Brazil). The metallic member consisted of unalloyed titanium (ASTM Grade 4, annealed). Table 1 shows some properties for both zirconia ceramics and metallic base materials.

Active-metal-free filler alloys with $50 \mu \mathrm{m}$ of thickness used as inserts were VH780 (Ag-28Cu) and VH950 (Au-18Ni), supplied by BrazeTec (Umicore AG \& Co.KG). The eutectic $\mathrm{Ag}-\mathrm{Cu}$ based filler alloy is usually preferred for brazing ceramic to ceramic or to metals because it is chemically inert and ductile, which reduces the oxidation behavior at the interface and therefore minimizes residual stresses during cooling at the end of the joining process $[7-9,12]$. With respect to $\mathrm{Au}-18 \mathrm{Ni}$ filler, gold has excellent thermal conductivity $(315 \mathrm{~W} / \mathrm{m} . \mathrm{K})$ and resistance to oxidation, with very high ductility, which is also beneficial to accommodate thermal stresses via interfacial plastic flow [6]. An obvious consideration about fillers is that they must have their liquidus temperature higher than the work temperature of the brazing joint, but lower than the component's melting temperature.

Moreover, zirconia stabilized with yttria or magnesia is wet and strongly bonded by the eutectic $\mathrm{Ag}-\mathrm{Cu}$ filler alloy even with small Ti contents in its composition [9].

Titanium specimens were manually cleaned with ethanol to remove machining residues and later ultrasonically cleaned in ethanol bath. Ceramic surfaces were polished with $1 \mu \mathrm{m}$ diamond and cleaned in ultrasonic acetone bath for 10 minutes. Brazing of zirconia $\left(\mathrm{ZrO}_{2}\right)$ to titanium was made under highvacuum higher than $3 \times 10^{-5}$ mbar (Pfeiffer, MOV262), using a simple butt-joint configuration according to scheme shown in Fig. 1. This configuration was also useful for helium gas leak detection at room temperature (Inficon UL200 equipment) in accordance to DIN EN 1779 standard.

Each joint assemble was submitted to a pressure of approximately $90 \mathrm{kPa}$ on its top by using a small mass on top of a set of 4 samples, which were fixed together to avoid eventual misalignments. Tests were executed three times for each group of base materials and fillers for its respective experimental conditions. 
Table 1. Properties of the base materials and filler alloys used in the study (manufacturer's data).

\begin{tabular}{|c|c|c|c|c|c|}
\hline \multirow[b]{2}{*}{ Properties } & \multicolumn{5}{|c|}{ Components of the joint assemble } \\
\hline & Y-TZP ceramic & Mg-PSZ ceramic & Titanium & $\begin{array}{c}\text { VH780 } \\
(\mathrm{Ag}-28 \mathrm{Cu})\end{array}$ & $\begin{array}{c}\text { VH950 } \\
\text { (Au-18Ni) }\end{array}$ \\
\hline Purity / Composition (wt.\%) & $\begin{array}{c}99.0-99.2 \% / \\
5.0-10.0 \% \mathrm{Y}_{2} \mathrm{O}_{3} \\
\mathrm{ZrO}_{2} \text { balance }\end{array}$ & $\begin{array}{c}99.0-99.2 \% / \\
3.0-4.5 \% \mathrm{MgO} \\
\mathrm{ZrO}_{2} 90.0-95.0 \%\end{array}$ & $\begin{array}{l}\text { ASTM } \\
\text { Grade } 4\end{array}$ & $\begin{array}{c}71.0-73.0 \% \mathrm{Ag} \\
\mathrm{Cu} \text { balance }\end{array}$ & $\begin{array}{l}81.5-82.5 \% \mathrm{Au} \\
17.5-18.5 \% \mathrm{Ni}\end{array}$ \\
\hline Apparent density, $20^{\circ} \mathrm{C}\left(\mathrm{g} / \mathrm{cm}^{3}\right)$ & $5.5-6.1$ & $5.1-5.6$ & 4.5 & 10.0 & 15.96 \\
\hline Linear CTE $\left(\times 10^{-6}{ }^{\circ} \mathrm{C}^{-1}\right)$ & $\begin{array}{c}10.4 \\
\left(25-1000^{\circ} \mathrm{C}\right)\end{array}$ & $\begin{array}{c}10.0-10.1 \\
\left(25-1000^{\circ} \mathrm{C}\right)\end{array}$ & $\begin{array}{c}9.2 \\
\left(20-250^{\circ} \mathrm{C}\right)\end{array}$ & $\begin{array}{c}17.8 \\
\left(20-400^{\circ} \mathrm{C}\right)\end{array}$ & $\begin{array}{c}14.6 \\
\left(20-550^{\circ} \mathrm{C}\right)\end{array}$ \\
\hline E modulus (GPa) & 206 & 204 & 105 & 100 & - \\
\hline Hardness (HRC) & 83 & 76 & 23 & - & - \\
\hline $\mathrm{T}$ working $\left({ }^{\circ} \mathrm{C}\right)$ & 1200 & 1000 & - & 780 (eutectic) & 950 (eutectic) \\
\hline
\end{tabular}
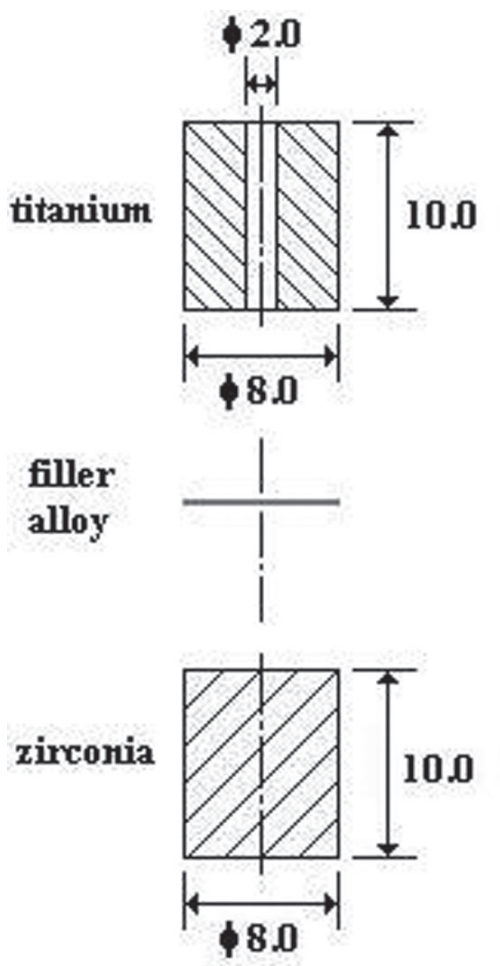

Figure 1. Joint configuration used for He gas leak tests and microstructural analysis. Dimension in $\mathrm{mm}$.

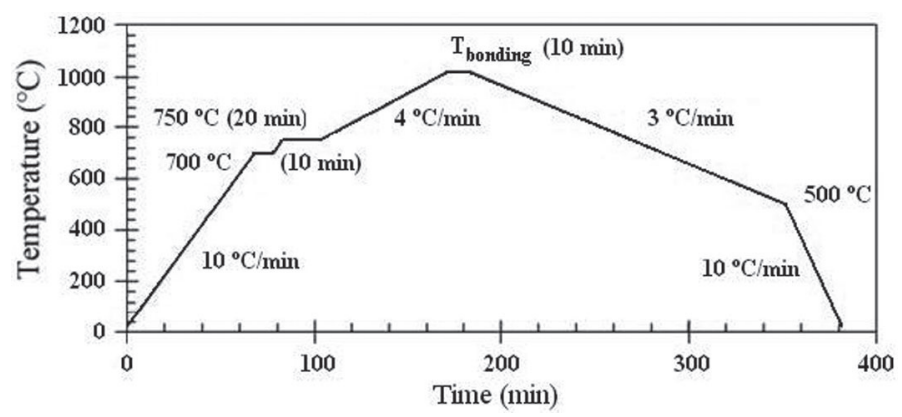

Figure 2. Standard thermal cycle for the joining process tested.
The standard thermal cycle used for the joining process tested in this study is shown in Fig. 2. There are two temperature homogenization levels, $700^{\circ} \mathrm{C}$ and $750^{\circ} \mathrm{C}$, and the third level (soaking $10 \mathrm{~min}$ ) is specific for brazing temperature, depending on the chosen filler/insert. Usually, the temperatures selected for experimental activities can be at least $30-50^{\circ} \mathrm{C}$ over the liquidus temperature of the filler alloy $[1,8]$. Tests for $\mathrm{ZrO}_{2} / \mathrm{Ag}-28 \mathrm{Cu} / \mathrm{Ti}$ and $\mathrm{ZrO}_{2} / \mathrm{Au}-18 \mathrm{Ni} / \mathrm{Ti}$ joint assembles were made at $820^{\circ} \mathrm{C}$ and $980^{\circ} \mathrm{C}$, respectively.

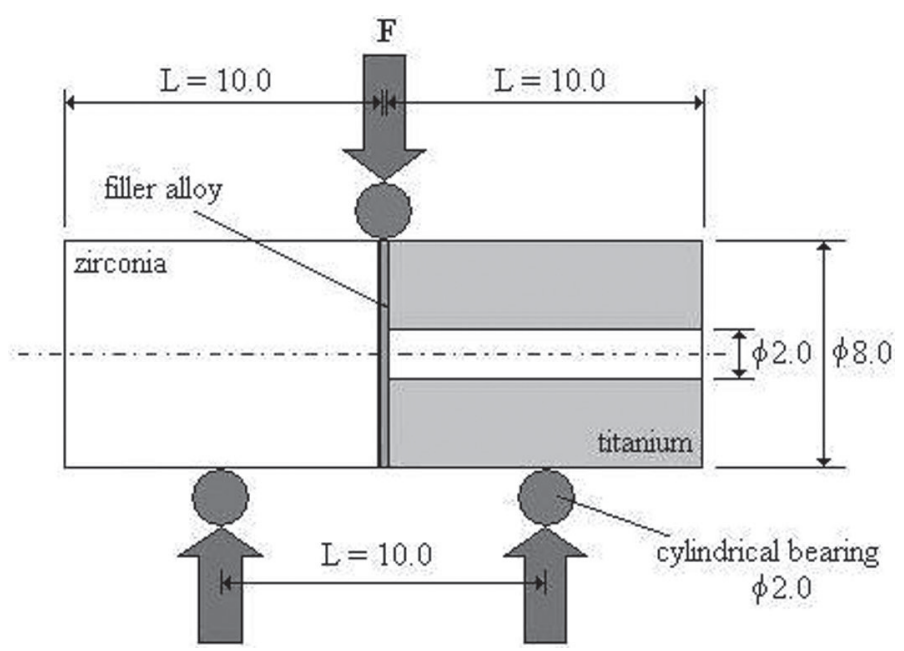

Figure 3. Three-point fixture configuration used in the study. F means load applied (in $\mathrm{N}$ ); dimension in $\mathrm{mm}$.

Samples were selected from vacuum tight joints for microstructural analysis at the ceramic/filler interface: mounted in epoxy and cut on low-speed diamond wire; grinded using diamond grinding paper (76 $\mu \mathrm{m}, 40 \mu \mathrm{m}, 20 \mu \mathrm{m}, 10 \mu \mathrm{m})$; polished on diamond suspension $(6 \mu \mathrm{m}$ and $3 \mu \mathrm{m})$ and submitted to final polishing using $0.025 \mu \mathrm{m} \mathrm{SiO}_{2}$ colloidal silica polishing suspension. The cross-section of the joint interface was analyzed by optical and scanning electron microscopy (SEM) using backscattered electron image (BEI). It was used a Shimadzu SSX- 
550 equipment equipped with linescan technique by energy dispersive X-ray analysis (EDX), operating voltage of $20 \mathrm{kV}$; and JEOL JSM-6390LV equipped with Thermo Scientific equipment.

Another group of tight brazed joints was submitted to threepoint flexure - eight samples were tested for each analyzed experimental condition, including a standard deviation results. It was used an EMIC DL-3000 Universal Materials Testing Machine with $5 \mathrm{kN}$ load cell and cross head speed of $0.5 \mathrm{~mm} /$ min (see schematic illustration in Fig. 3), according to ASTM C1161-02c standard.

\section{Results and Discussion}

\subsection{Vacuum tightness of the joints}

Results of vacuum tightness of ceramic/metal joints at room temperature are summarized in Table 2. Leak rates bellow 10-8 mbar.. $\mathrm{s}^{-1}$ were considered satisfactory for $\mathrm{ZrO} / \mathrm{Ag}-28 \mathrm{Cu} /$ Ti joints using both Y-TZP and Mg-PSZ ceramic. In this case, it was suggested that $\mathrm{Ti}$ diffusion from the metallic member possibly allowed reduction reactions of zirconium oxide on the ceramic surface due to the joining process. It is believed that the addition of $\mathrm{Ti}$ to $\mathrm{Ag}-28 \mathrm{Cu}$ filler alloy promotes drastically lower contacts, improving wetting and adhesion on the ceramic substrate $[1,5,6,10]$. Moreover, reliable vacuum tight joints from this group were selected for microstructural analysis.

The joining process for $\mathrm{ZrO}_{2} / \mathrm{Au}-18 \mathrm{Ni} / \mathrm{Ti}$ joints was considered not possible because the joint assembles were weakly joined in the end of process. It was suggested that Ti diffusion across the molten filler alloy towards the ceramic surface did not result in Au-Ni active solid solution sufficiently capable for reducing zirconium oxide. Probably it inhibited the formation of a reaction layer to enhance sound bonding between the ceramic and the metallic member. Nascimento et al. [15] had concluded that no reaction layer was observed upon brazing alumina previously metallized with $\mathrm{Ti}$ to $\mathrm{Fe}-\mathrm{Ni}$-Co alloy using the Au$18 \mathrm{Ni}$ filler at $950^{\circ} \mathrm{C}$. In addition, low tightness and poor joining process were observed for both types of zirconia ceramic when the $\mathrm{Au}-18 \mathrm{Ni}$ filler was used in the joint assembles.

Table 2. Summarized results of helium gas leak detection at room temperature.

\begin{tabular}{|c|c|}
\hline \multicolumn{2}{|c|}{ Brazing at $820^{\circ} \mathrm{C} / 10 \mathrm{~min}, \mathrm{VH} 780(\mathrm{Ag}-28 \mathrm{Cu})$} \\
\hline Joints & Leak rate $\left(\mathrm{mbar}\right.$. . $\left.^{-1}\right)$ \\
\hline $\begin{array}{c}\text { Y-TZP/Ag- } 28 \mathrm{Cu} / \mathrm{Ti} \\
\mathrm{Mg}-\mathrm{PSZ} / \mathrm{Ag}-28 \mathrm{Cu} / \mathrm{Ti}\end{array}$ \\
\hline \multicolumn{2}{|c|}{ Brazing at $980^{\circ} \mathrm{C} / 10 \mathrm{~min}$, VH980 $(\mathrm{Au}-18 \mathrm{Ni})$} \\
\hline Joints & Leak rate $\left(\mathrm{mbar}\right.$. . $\left.^{-1}\right)$ \\
\hline $\mathrm{Y}-\mathrm{TZP} / \mathrm{Au}-18 \mathrm{Ni} / \mathrm{Ti}$ & No brazing \\
$\mathrm{Mg}-\mathrm{PSZ} / \mathrm{Au}-18 \mathrm{Ni} / \mathrm{Ti}$ & \\
\hline
\end{tabular}

Schröder et al. [17] consider that the maximum allowable leak rate for most cases of technical application is $10^{-6}-10^{-8}$ mbar. $\ell . \mathrm{s}^{-1}$. These researchers suggested that leak values bellow $10^{-8}$ mbar.. $\mathrm{s}^{-1}$ may classify components as vacuum tight, which means that there would be approximately $3 \mathrm{ml}$ of He gas loss within 1 year through a discontinuity diameter $\approx 0,4 \mu \mathrm{m}$. They also suggested that only extremely low leak rates $\left(<10^{-10}\right.$ mbar.. $\left.\mathrm{s}^{-1}\right)$ can technically classify vacuum tight components.

Knowledge on the wetting behavior using selected fillers was important for the development of this joining process, which is a key factor to produce sound ceramic/metal joints. The selected temperatures of $820^{\circ} \mathrm{C}$ and $980^{\circ} \mathrm{C}$ were expected to be optimum using the eutectic $\mathrm{Ag}-28 \mathrm{Cu}$ and $\mathrm{Au}-18 \mathrm{Ni}$ filler alloy for improving wetting on the ceramic surface. Generally, these temperatures for experimental activities are at least $30-50^{\circ} \mathrm{C}$ over the liquidus of fillers [1]. For instance, researches have already reported that active brazing temperatures around $820^{\circ} \mathrm{C}$ ensure the formation of a continuous reaction layer between the ceramic and the filler alloy in the case of brazed PSZ/Ti joints $[5,9,18]$. Moreover, these temperature values are interesting to prevent excessive grain growth in $\beta$-phase field of the unalloyed titanium because $\alpha \rightarrow \beta$ transus temperature is $950^{\circ} \mathrm{C}[19]$.

\subsection{Darkening effect in zirconia ceramic}

The darkening in zirconia near the joined ceramic/metal interface is shown in Fig. 4. Visually, this dark area was notably more pronounced in Mg-PSZ than in Y-TZP ceramic using the same thermal cycle with $\mathrm{Ag}-28 \mathrm{Cu}$ filler for brazing tests. It was just observed that at higher temperatures in separated test at $880^{\circ} \mathrm{C}$, darkening was a little more extensive from the joined interface using the materials mentioned before. The darkening effect and its consequences about mechanical properties in zirconia ceramic were not investigated here.

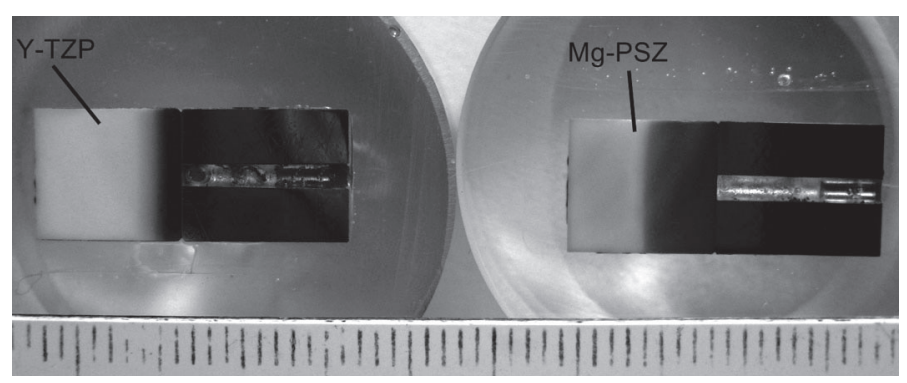

Figure 4. Darkening effect in zirconia ceramic at the joint interface; brazing at $820^{\circ} \mathrm{C} / 10 \mathrm{~min}$. Dimension in $\mathrm{mm}$.

Researchers have already reported this typical darkening effect in zirconia at the ceramic/metal joints interface for active brazing with commercial fillers containing $\mathrm{Ti}$ as active metal $[6,12,17]$. It has been proposed that this phenomenon is attributed to the formation of non-stoichiometric zirconia $(\mathrm{ZrO} 2-\mathrm{X}$, where $0<\mathrm{X} \leq 0.02$ ), in which zirconia may lose oxygen due to the high chemical affinity of active metal for oxygen, which leads to O-deficient area that appears dark $[8,9]$. The darkening effect in zirconia ceramic can be influenced by some factors $[1,20]$ : permanence time at brazing temperature; substrate to which zirconia is being joined; percentage of active metal in the filler composition; and structure ceramic associated to the working 
Table 3. Comparison of the three-point flexure test results with literature values.

\begin{tabular}{|c|c|c|c|}
\hline \multicolumn{4}{|c|}{ Brazing at $820^{\circ} \mathrm{C} / 10 \mathrm{~min}$, filler VH780 (Ag-28Cu) with no previous metallization } \\
\hline zirconia & active metal & ceramic/metal joint & Mechanical strength \\
\hline $\begin{array}{c}\text { Y-TZP, } \\
\text { Mg-PSZ }\end{array}$ & $\begin{array}{c}\mathrm{Ti} \\
\text { (diffusion from base metal) }\end{array}$ & $\begin{array}{c}\text { Y-TZP/Ag-28Cu/Ti } \\
\mathrm{Mg}-\mathrm{PSZ} / \mathrm{Ag}-28 \mathrm{Cu} / \mathrm{Ti}\end{array}$ & $32 \pm 9 \mathrm{MPa}$ \\
\hline \multicolumn{4}{|c|}{ Brazing at $840^{\circ} \mathrm{C} / 5 \mathrm{~min}$, filler Cusil-ABA (63Ag-35,25Cu-1,75Ti) [9] } \\
\hline zirconia & active metal & ceramic/metal joint & Mechanical strength \\
\hline 3Y-PSZ & $\begin{array}{c}\text { Ti } \\
\text { (active brazing) }\end{array}$ & 3Y-PSZ/Ag-28Cu/Ti & $242 \pm 18 \mathrm{MPa}$ \\
\hline
\end{tabular}

temperature - monocrystals zirconia turn fully black and the dark zone is usually formed on the polycristals zirconia surface. Besides the undesirable aesthetical aspect, there was not any measurable negative effect for mechanical strength due to this noticeable dark region in zirconia ceramic [1,9].

\subsection{Mechanical properties of joints}

The mechanical strength of the tight $\mathrm{ZrO} / \mathrm{Ag}-28 \mathrm{Cu} / \mathrm{Ti}$ joints for brazing tests at $820^{\circ} \mathrm{C} / 10$ min was evaluated by three-point flexure tests. Samples were strictly fixed to avoid detrimental misalignments during the brazing process.

Results were quite similar for both zirconia ceramics $(\mathrm{Mg}-$ PSZ and Y-TZP), which values are within the range of $32 \pm 9$ $\mathrm{MPa}$. The scattered strength results can be attributed to the concentration of thermal residual stresses at the joint interface as well as to the specific characteristics of ceramic materials when submitted to mechanical tests. However, these values were not comparatively as good as other values found in scientific literature (see some results from Smorygo's study [9] in Table 3).

Smorygo et al [9] obtained values within the range of 242 $\pm 18 \mathrm{MPa}$ for 3Y-PSZ/Ti joint strength $(\varnothing 8 \times 35 \mathrm{~mm})$, but in this case, active brazing process was used for joining zirconia to unalloyed titanium. Another important consideration is that probably, these researches used a length value between the outer two support bearings (support span, L, according to ASTM C1161-02c standard) in the three-point flexure tests, which is different and longer from the value used in the present study (joints $\varnothing 8 \times 10 \mathrm{~mm}$ and $\mathrm{L}=10 \mathrm{~mm}$ ). Considering the calculation for mechanical strength of the three-point flexure test, the specific difference about this parameter could indicate values somewhat higher than the mechanical strength values found in this study. For instance, if those researchers had used L $=20.0 \mathrm{~mm}$ and used this value in the calculation here, the new mechanical strength value would be also lower than that found in the literature searched $(32.5 \times 2=65 \mathrm{MPa}$ versus $242 \mathrm{MPa})$.

In addition, the possibility of residual thermal stresses due to mismatch between linear thermal expansion coefficient ( $\alpha$-CTE) of individual components should be also considered. The $\alpha$-CTE of unalloyed titanium $\left(9.2 \times 10^{-6}{ }^{\circ} \mathrm{C}^{-1}\right)$ is comparable to that of zirconia ceramic $\left(10.0-10.4 \times 10^{-6}{ }^{\circ} \mathrm{C}^{-1}\right)$. However, the $\alpha$-CTE value of the filler is higher than it $-\alpha$-CTE of the Ag-28Cu filler $\left(20-400^{\circ} \mathrm{C}\right)$ is $17.8 \times 10^{-6}{ }^{\circ} \mathrm{C}^{-1}$. According to these data, tensile strains can be developed at the ceramic/metal interface due to differential contraction during post-fabrication cooling. It is believed that residual stresses can be accommodate by plastic flow due to the high ductility of this filler alloy $[5,6,9]$.

\subsection{Microstructural analysis}

Figure 5 shows the microstructure at the brazing region, which is representative for $\mathrm{ZrO}_{2} / \mathrm{Ag}-28 \mathrm{Cu} / \mathrm{Ti}$ joint assembles using both zirconia ceramics (Mg-PSZ or Y-TZP) and suggests the formation of sound ceramic/metal joints. Initially, the optical micrograph shows three different regions at the resultant interface: a region composed of dispersed phases along with the ceramic/filler interface, and other two noticeable regions with distinct colors. There is a white region in the middle (thickness ranging from 4.5 to $16.5 \mu \mathrm{m}$ ), which is likely to have higher silver contents, and a continually thicker region that was formed closely to the metallic counterpart (brown color in this resolution, thickness from 10.5 to $17.5 \mu \mathrm{m}$ ), which is probably composed of higher titanium contents.

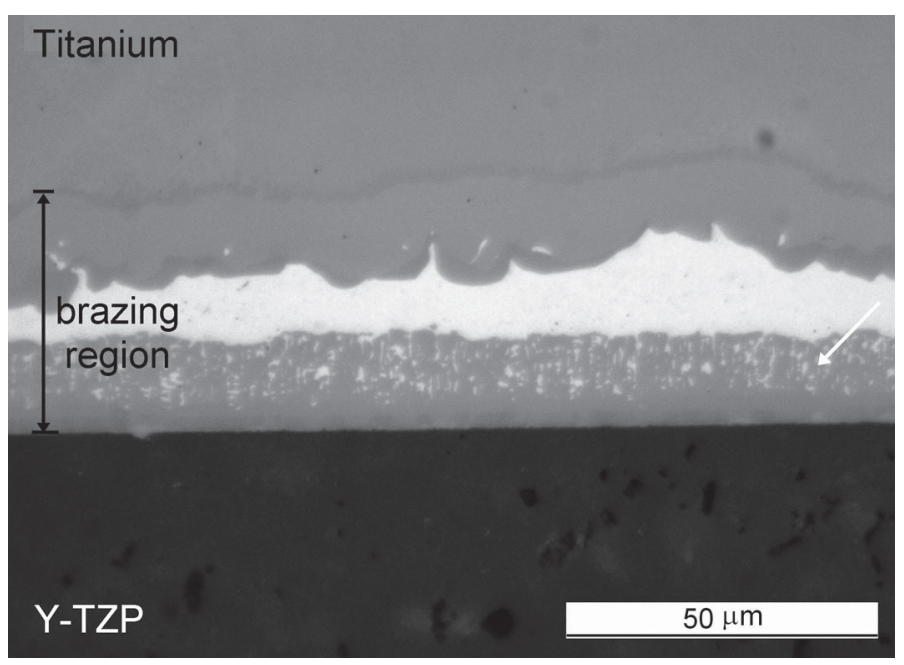

Figure 5. Optical micrograph at the Y-TZP/Ag-28Cu/Ti joint interface: region composed of

dispersed phases adjacent to the ceramic (see white arrow)

SEM image in Fig. 6 exhibits the same resultant interface of the ceramic/metal joint shown in Fig. 5. Specific regions can be identified here: one region produced in the metallic member called as diffusive zone; one intermetallic layer $(0,8-2,0 \mu \mathrm{m})$ at 
the filler/Ti interface; one region possibly composed of dispersed phases closely to the ceramic (as mentioned in previous Fig. 5); and one dark reaction sublayer on the ceramic surface. These dispersed phases mentioned before were not identified in this study. Similar interfacial regions were found in each examined sample and the microstructural analysis do not reveal noticeable difference about it.

Results from EDX analysis by linescan technique across the filler/Ti interface revealed the presence of diffusion of elemental $\mathrm{Cu}$ and $\mathrm{Ag}$ from the molten filler alloy to the metallic member during brazing thermal cycle, producing a diffusive zone and an intermetallic layer, as previously mentioned (see specific regions shown in Fig. 6). According to the average values of the elemental quantitative EDX analysis as indicated in Fig. 7, these two specific regions are both Ti-rich zones as following: 95.6 at. $\% \mathrm{Ti}, 3.5$ at. $\% \mathrm{Cu}$ and 0.9 at. $\% \mathrm{Ag}$ for intermetallic layer; and 94.3 at.\%Ti, 4.9 at.\% $\%$ and 0.8 at. $\% \mathrm{Ag}$ for diffusive zone. The small brown squares indicated in Fig. 7 represent the areas where elemental quantitative EDX analysis was executed at joint interface. The $\mathrm{CuTi}_{3}$ compound may have been produced in these regions, which follows from the $\mathrm{Cu}$-Ti equilibrium phase diagram shown in Fig. 8 and the quantitative analysis previously shown.

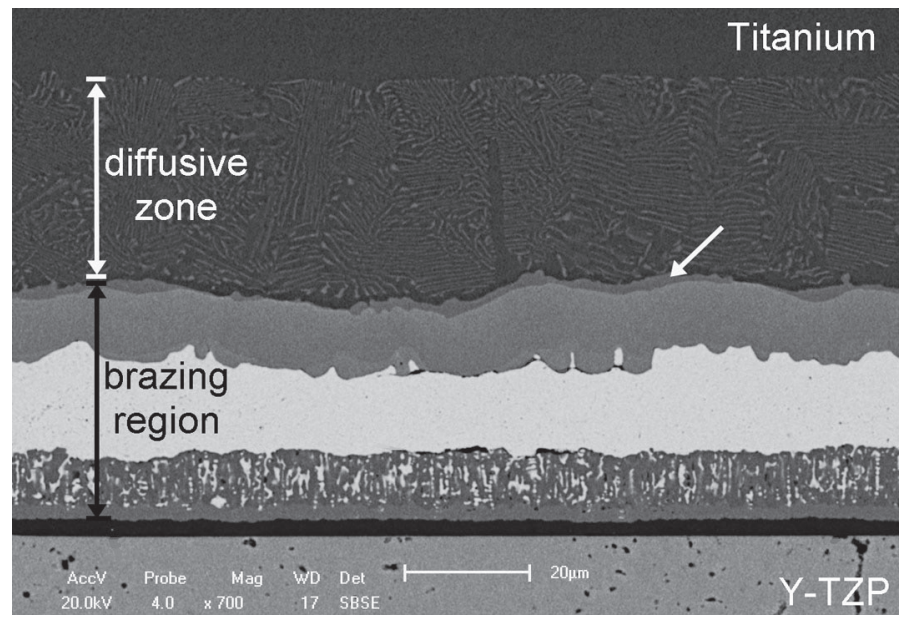

Figure 6. SEM image at the Y-TZP/Ag-28Cu/Ti joint interface: diffusive zone and intermetallic layer (see the white arrow); and a dark reaction sublayer on the ceramic surface.

Researchers have already reported the probable formation of $\mathrm{CuTi}$ and $\mathrm{CuTi}_{2}$ compounds at the $\mathrm{Ag}-28 \mathrm{Cu} / \mathrm{Ti}$ interface by active brazing of zirconia to titanium; the formation mechanism of the bond layer in this study can be explained by analyzing previously reported data $[9,21]$. It was suggested that copper has a strong tendency to rapid formation of intermetallics with titanium, and $\mathrm{Ag}$ is the less active element of $\mathrm{Ag}-\mathrm{Cu}$ filler alloys with low diffusivity through the CuTi layer; however, the presence of Ag can remarkably increase the activity of filler alloys to promote interfacial reactions with technically stable ceramics $[9,22,23]$. Other elements such as $\mathrm{V}, \mathrm{Cr}, \mathrm{Zr}, \mathrm{V}, \mathrm{Nb}$, Ta and Hf can also be considered chemically active in braze alloys composition - especially $\mathrm{Ti}$, which can make chemical interactions (dissolution, interdifusion and/or product formation reaction) at the ceramic/metal interfaces to enhance wetting on the ceramic surface $[5,6,24]$.

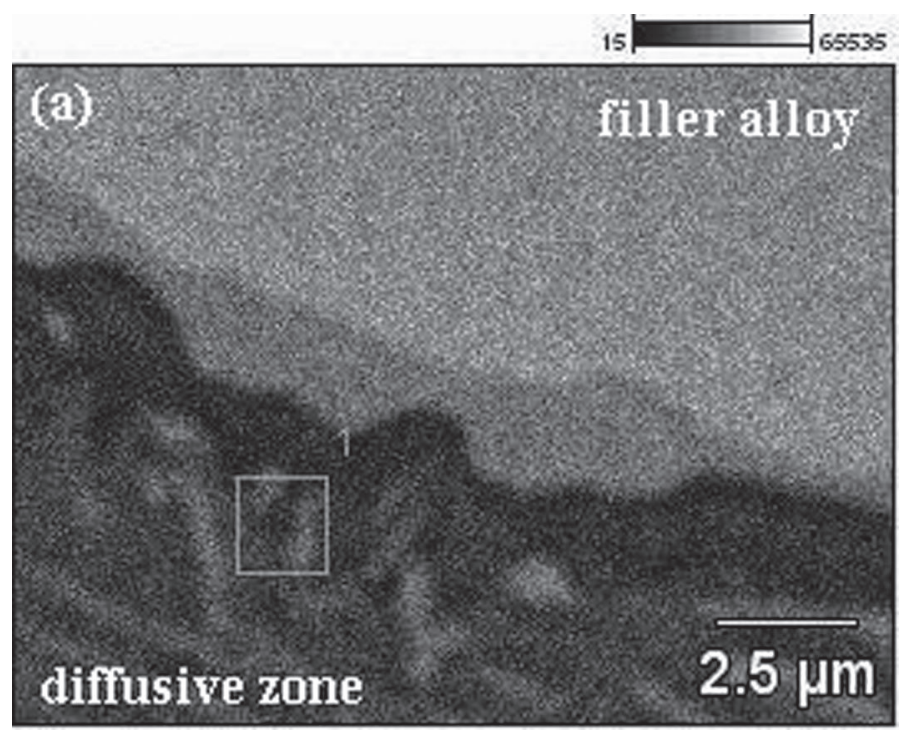

Figure7. Elemental quantitative EDX analysis (see the brown square areas) at Ti/Ag-28Cu interface: (a) diffusive zone; (b) intermetallic layer.

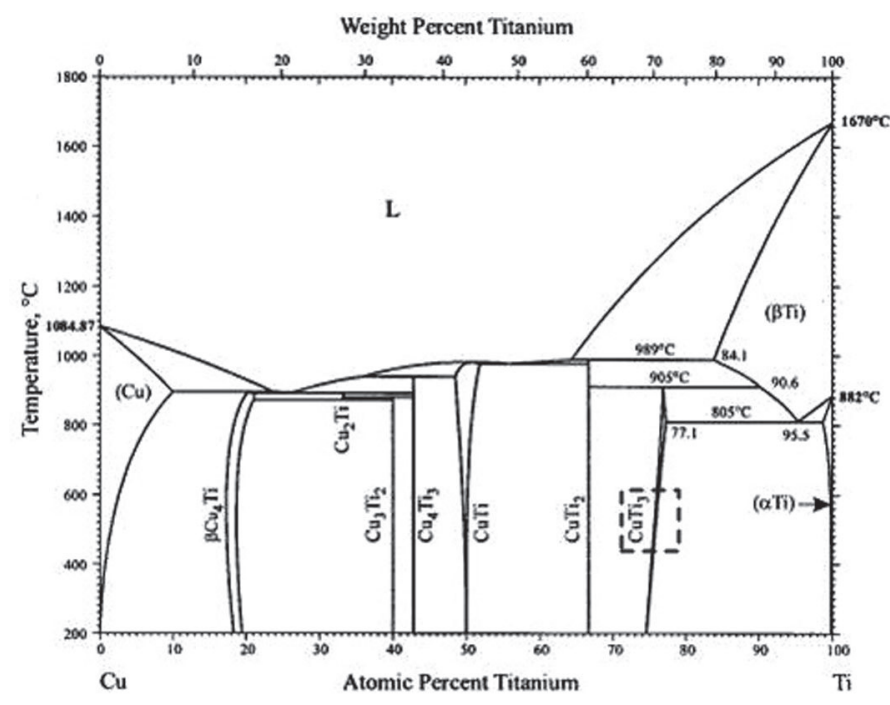

Figure 8. Probable phase formed in the intermetallic layer and diffusive zone at the filler/Ti interface

(see the square indication). $\mathrm{Cu}$-Ti equilibrium phase diagram [25].

Figure 9 exhibits the ceramic/filler interface with higher magnification from the region shown in Fig. 6. Scanning electron image shown in Fig. 9a revealed another intermetallic layer $(1,7-2,7 \mu \mathrm{m})$ at the resulting interface, but now between the dispersed phases region ( $d-p$ region) and the dark reaction of the sublayer $(2,0-2,5 \mu \mathrm{m})$ next to the ceramic surface. EDX profiles by linescan technique across this interface are shown in Fig. 9b. The bulk of molten filler alloy was enriched with $\mathrm{Ti}$ as a result of its diffusion from the metallic member to the zirconia ceramic. The elemental $\mathrm{Ti}, \mathrm{Ag}$ and $\mathrm{Cu}$, were detected in the $d-p$ region where some intermetallic phases may have been 


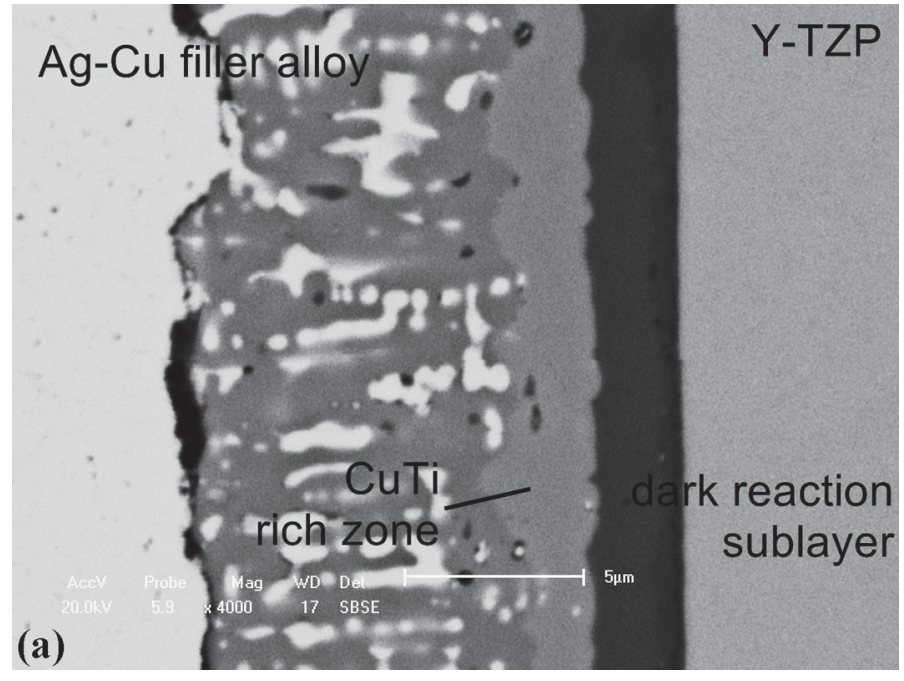

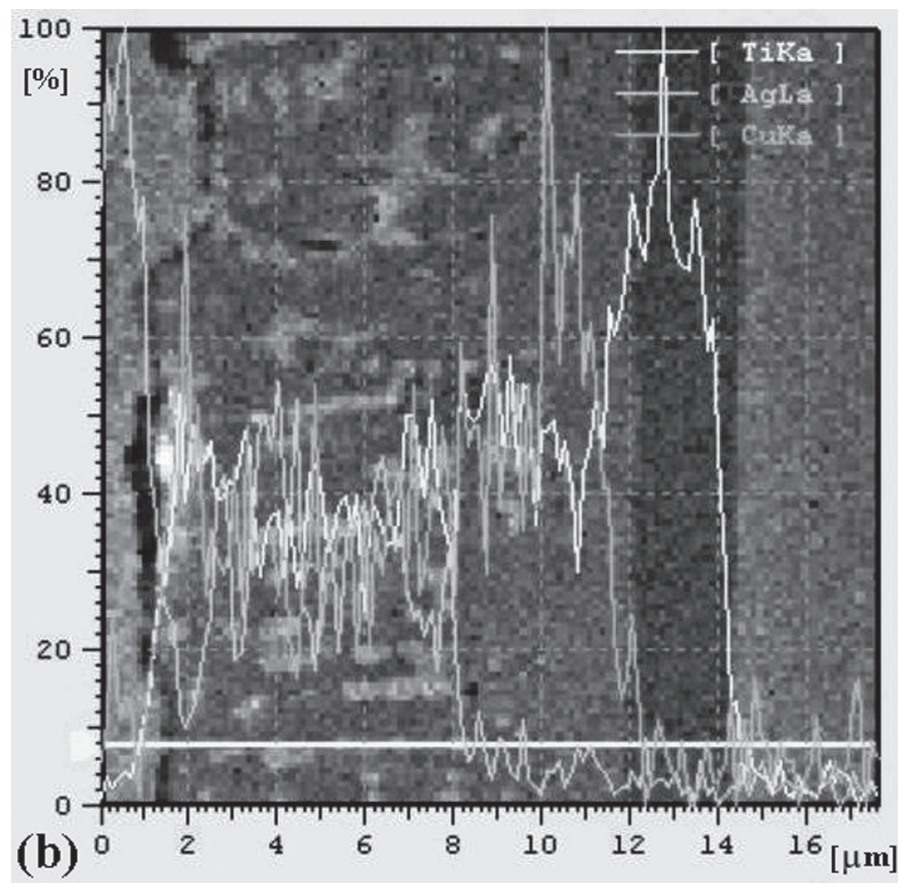

Figure 9. (a) SEM image at the filler/Y-TZP interface previously shown in Fig. 6b; (b) EDX profiles by linescan technique for Ti, Ag and $\mathrm{Cu}$.

produced; lower EDX levels for the elemental $\mathrm{Zr}$ and $\mathrm{Y}$ were also detected in the molten filler. It occurred due to the reduction of $\mathrm{ZrO}_{2}$ and $\mathrm{Y}_{2} \mathrm{O}_{3}$ by titanium, which are the main oxides in the zirconia ceramic composition. According to the elemental quantitative EDX analysis, this intermetallic layer contains Ti $(\approx 54$ at.\%) and $\mathrm{Cu}(\approx 36$ at.\%) in similar equiatomic amounts, characterizing a CuTi-rich zone $-\mathrm{Ag}(\approx 4$ at.\%), $\mathrm{O}(\approx 5$ at.\%) and $\mathrm{Zr}(\approx 1$ at.\%) were also found in less percents here. The probable formation of $\mathrm{CuTi}$ compounds in this layer also follows the $\mathrm{Cu}-$ Ti equilibrium phase diagram (see indication in Fig. 8) and in its elemental quantitative analysis.

This continuous dark reaction sublayer is not exactly the region previously visualized in Fig. 4 (darkening effect). It is a specific reaction layer that was formed next to the ceramic surface from the chemical reduction of zirconium oxide by the active metal (Ti) on the zirconia ceramic surface. Higher EDX level of the elemental Ti was found (see Fig. 9b), which contains the following distribution: Ti ( $\approx 63$ at.\%), O $(\approx 18,5$ at.\%), $\mathrm{Cu}$ $(\approx 11$ at.\%), $\mathrm{Ag}(\approx 1,5$ at.\%) and $\mathrm{Zr}(\approx 6$ at.\%). Researchers have reported that this dark layer is mainly composed of $\mathrm{TiO}_{\mathrm{x}}$ compounds ( $\mathrm{TiO}, \mathrm{Ti}_{2} \mathrm{O}_{3}, \mathrm{Ti}_{3} \mathrm{O}_{5} \ldots \mathrm{TiO}_{2}$ ), which is beneficial to improve wetting on the ceramic surface due to the subsequent precipitation of active metal oxides [5,9].

Scanning electron image associated to the EDX analysis for the elemental $\mathrm{Ti}, \mathrm{Y}, \mathrm{Ag}$ and $\mathrm{Cu}$ by linescan technique are shown in Fig. 10 from a region at the interface previously shown in Fig. 6. According to results, Ti diffusion was confirmed from the metallic member across the bulk of molten filler alloy to the ceramic surface. There was also $\mathrm{Y}$ and $\mathrm{Zr}$ diffusion into the depth of the molten filler. It is recognized that titanium drastically reduces the contact angle with the ceramic substrate, improving the ceramic/filler adhesion by reacting with the oxide that constitutes the main phase of the ceramic [5]. The elemental Ag and $\mathrm{Cu}$ are concentrated in the two well-distinguished regions at the brazing joint interface previously shown in Fig. 5 and Fig. 6: the white region is an $\mathrm{Ag}$-rich zone, and the adjacent gray region is a CuTi-rich zone.

In addition, chemical interactions between individual components of the joint assemble should also be considered in the study. Possible reactions of the zirconium oxide $\left(\mathrm{ZrO}_{2}\right)$ from zirconia ceramic with Ti are shown in Table 4 - corresponding values of Gibb's free energy change, $\Delta G$, are given for these reactions between $\mathrm{ZrO}_{2}$ and $\mathrm{Ti}$ at $850^{\circ} \mathrm{C}$. Titanium is considered an effective active metal to enhance the ceramic-metal wettability, especially in ceramic oxides because it exhibits strong thermodynamic affinity with oxygen $[1,8]$.

Table 4. Chemical reactions between $\mathrm{Ti}$ and $\mathrm{ZrO}_{2}$ from zirconia ceramic and respective values of Gibb's free energy change

$(\Delta G)[1]$.

\begin{tabular}{cc}
\hline Reactions with $\mathrm{ZrO}_{2}$ & $\Delta G(\mathrm{~kJ} / \mathrm{mol})$ at $850^{\circ} \mathrm{C}$ \\
\hline $\mathrm{ZrO}_{2}+2 \mathrm{Ti} \rightarrow \mathrm{Zr}+2 \mathrm{TiO}$ & $+14,7$ \\
$\mathrm{ZrO}_{2}+(4 / 3) \mathrm{Ti} \rightarrow \mathrm{Zr}+(2 / 3) \mathrm{Ti}_{2} \mathrm{O}_{3}$ & $+79,7$ \\
$\mathrm{ZrO}_{2}+(6 / 5) \mathrm{Ti} \rightarrow \mathrm{Zr}+(2 / 5) \mathrm{Ti}_{3} \mathrm{O}_{5}$ & $+102,6$ \\
$\mathrm{ZrO}_{2}+(8 / 7) \mathrm{Ti} \rightarrow \mathrm{Zr}+(2 / 7) \mathrm{Ti}_{4} \mathrm{O}_{7}$ & $+113,9$ \\
$\mathrm{ZrO}_{2}+\mathrm{Ti} \rightarrow \mathrm{Zr}+\mathrm{TiO}_{2}$ & $+145,1$ \\
\hline
\end{tabular}

The positive $\Delta G$ values per mole of $\mathrm{ZrO}_{2}$ shown in Table 4 that predict the formation of titanium oxides by a simple direct reduction of zirconium and yttrium oxides are not thermodynamically favorable at $850^{\circ} \mathrm{C}$. However, it might be 


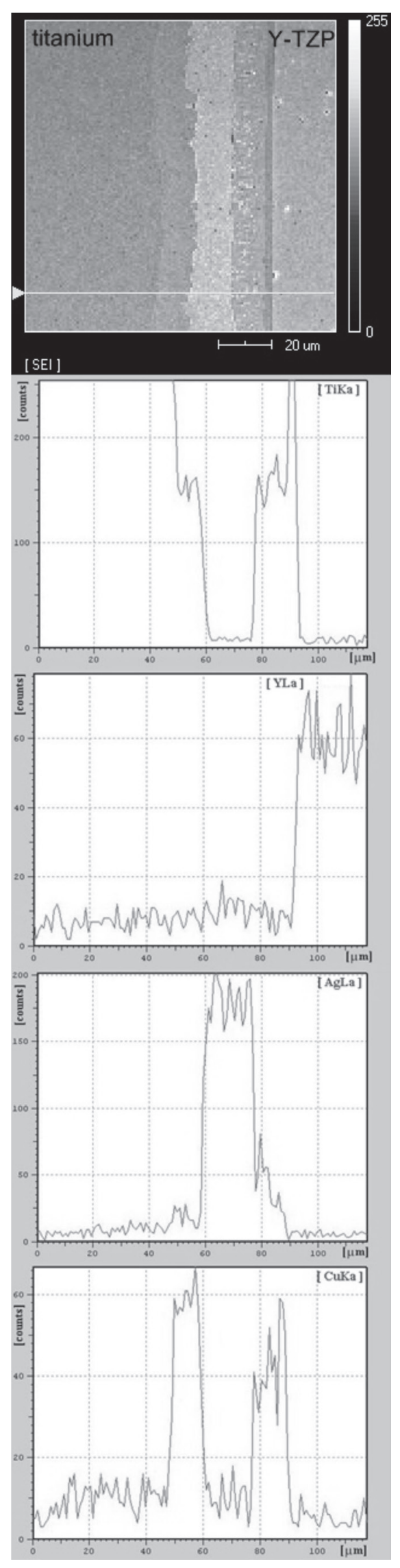

Figure 10. SEM image and EDX profiles for elemental Ti, Y, $\mathrm{Ag}$ and $\mathrm{Cu}$ by linescan technique across the interface. possible to produce these oxides from the reaction of $\mathrm{Ti}$ with residual oxygen in the brazing furnace atmosphere, if not just from the direct chemical reduction of $\mathrm{ZrO}_{2}$ and $\mathrm{Y}_{2} \mathrm{O}_{3}$ constituents on the zirconia ceramic surface [6]. Probably, it occurs in few atomic levels into the depth of the ceramic surface, which can have some influence on the $\Delta G$ values calculation for these oxides. It is also believed that stable Ti oxides can be formed even at oxygen partial pressure as low as $p_{\mathrm{O} 2} \approx 10^{-28}$ atm [8]. Researchers have already proposed that $\mathrm{Ti}$ can act as an oxygen scavenger in zirconia, which changes its stoichiometry by producing an O-deficient area at the joined interface that appears dark $[6,12]$.

\section{Conclusion}

Zirconia was successfully joined to unalloyed titanium using eutectic $\mathrm{Ag}-28 \mathrm{Cu}$ filler alloy. Titanium diffusion from the metallic counterpart to the ceramic surface produced sound brazing joints. Results based on helium gas leak detection were satisfactory with leak rates bellow $10^{-8}$ mbar.. . $^{-1}$, which characterize vacuum tight components. Microstructural analysis revealed the formation of a continuous dark reaction sublayer next to the ceramic surface (responsible for the good wetting condition), an intermetallic layer adjacent to this dark layer and a noticeable dispersed phases region at the ceramic/filler interface. A typical darkening effect occurred at the zirconia brazed joint interface. Visually, this effect was more pronounced in Mg-PSZ than in Y-TZP ceramic. The mechanical strength results of tight brazed joints were comparatively not as good as the other results found in scientific literature, in which was used an active filler alloy for joining ceramic to metal. It was possible to successfully braze $\mathrm{Y}-\mathrm{TZP} / \mathrm{Ag}-28 \mathrm{Cu} / \mathrm{Ti}$ and $\mathrm{Mg}-\mathrm{PSZ} / \mathrm{Ag}-$ $28 \mathrm{Cu} / \mathrm{Ti}$ joints using an active-metal-free filler alloy. However, the mechanical strength of these ceramic-metal joints still needs to be improved.

\section{Acknowledgements}

The authors would like to thank the Forschungszentrum Juelich team (Germany) for their partnership and technical assistance in the study. J.S. Pimenta acknowledges the CapesBR/DAAD PROBRAL Project for this international cooperation research and the $\mathrm{CNPq}$ agency for granting his doctorate scholarship in Brazil. J.S. Pimenta would also like to thank the CTGAS team (Natal-RN, Brazil), LCME team at UFSC (Brazil) for scanning electron microscopy services and the GRANTE Laboratory team at UFSC for three-point flexure test.

\section{References}

[1] HANSON, W.B.; IRONSIDE, K.I.; FERNIE, J.A. Active metal brazing of zirconia. Acta Mater., v.48, p.4673-4676, 2000. [2] KELLY, J.R.; DENRY, I. Stabilized zirconia as a structural ceramic: An overview. Dental Mater., v.24, p.289-298, 2008. [3] YOSHIKAWA, N.; KIKUCHI, A.; TANIGUCHI, S. Tetragonal to monoclinic transformation in Y-TZP joined with metallic materials. J. Mater. Sci., v.34, p.5885-5891, 1999. 
[4] ROEBBEN, G.; et al. Transformation-induced damping behaviour of Y-TZP zirconia ceramics. J. Eur. Ceram. Soc., v.23, p.481-489, 2003.

[5] SCITI, D.; BELLOSI, A.; ESPOSITO, L. Bonding of zirconia to super alloy with the active brazing technique. J. Eur. Ceram. Soc., v.21, p.45-52, 2001.

[6] SINGH, M.; SHPARGEL, T.P.; ASTHANA, R. Brazing of yttria-stabilized zirconia (YSZ) to stainless steel using $\mathrm{Cu}, \mathrm{Ag}$, and Ti-based brazes. J. Mater. Sci., v.43, n.1, p.23-32, 2008.

[7] LIU, G.W.; et al. Microstructures and interfacial behavior of zirconia/stainless steel joint prepared by pressureless active brazing. J. Alloy Compound, v.470, p.163-167, 2009.

[8] SINGH, M.; SHPARGEL, T.P.; ASTHANA, R. Brazing of stainless steel to yttria-stabilized zirconia using gold-based brazes for solid oxide fuel cell applications. Int. J. of Appl. Ceram. Technol., v.4, n.2, p.119-133, 2007.

[9] SMORYGO, Q.; et al. Evolution of the interlayer microstructure and the fracture modes of the zirconia/ $\mathrm{Cu}-\mathrm{Ag}-$ Ti filler/Ti active brazing joints. Mater. Lett., v.61, p.613-616, 2007.

[10] ELSSNER, G.; PETZOW, G. Review - metal/ceramic joining. ISIJ Int., v.30, n.12, p.1011-1032, 1990.

[11] SUGANUMA, K. Review - recent advances in joining technology of ceramics to metals. ISIJ Int., v.30, n.12, p.10461058, 1990.

[12] MUOLO, M.L.; FERRERA, E.; MORBELLI, L. Wetting, spreading and joining in the alumina-zirconia-Inconel 738 system. Scripta Mater., v.50, p.325-330, 2004.

[13] NASCIMENTO, R.M.; MARTINELLI, A.E.; BUSCHINELLI, A.J.A. Artigo Revisão: Avanços recentes em brasagem metal-cerâmica. Cerâmica, v.49, p.178-198, 2003.

[14] NASCIMENTO, R.M.; et al. Brazing metals to ceramics mechanically metallized with titanium. In: PROC. $6^{\text {th }}$ INT. CONF. ON JOINING CERAMIC, GLASS AND METAL, Munich, Germany, 2002, p.58-65.

[15] NASCIMENTO, R.M.; et al. Interface microstructure of alumina mechanically metallized with $\mathrm{Ti}$ brazed to $\mathrm{Fe}-\mathrm{Ni}-\mathrm{Co}$ using different fillers. Mater. Sci. Eng. A, v.466, p.195-200, 2007.

[16] LÖFFLER, F. Functional metal-based coatings on ceramic substrates. Surf. Coat. Technol., v.132, p.222-227, 2000.

[17] SCHRÖDER, G.; FILHO, J.C.P.; SCHMIDT, W. Fundamentos de Ensaio de Vazamento e Estanqueidade (in Portuguese), FZ-Jülich GmbH, Jülich, Germany, 2000. 95 p.

[18] HAO, H.Q.; et al. Joining of zirconia to zirconia using Ag$\mathrm{Cu}$-Ti filler metal. J. Mater. Process. Technol., v.52, p.238-247, 1995.

[19] ASM Data Sheet. Disponível em: <http://asm.matweb. $\mathrm{com} / \mathrm{search} /$ SpecificMaterial.asp?bassnum=MTU041 $>$.

Accesso em: 25 maio 2009.

[20] DUROV, A.V.; NAIDICH, Y.V.; KOSTYUK, B.D.; Joining of zirconia to metal with $\mathrm{Cu}-\mathrm{Ga}-\mathrm{Ti}$ and $\mathrm{Cu}-\mathrm{Sn}-\mathrm{Pb}-\mathrm{Ti}$ fillers. J. Mater. Sci., v.43, p.2173-2178, 2005.

[21] GUEDES, A.; et al. Multilayered interface in Ti/Macor ${ }^{\circledR}$ machinable glass-ceramic joints. Mater. Sci. Eng. A, v.301, p.118-124, 2001.

[22] ANDRIEUX, J.; et al. Low-temperature interface reaction between titanium and the eutectic silver-cooper brazing alloy. J. Phase Equilibria, v.30, p.40-45, 2009.

[23] ARRÓYAVE, R.; EAGAR, T.W. Metal substrate effects on the thermochemistry of active brazing interfaces. In: Proc. $58^{\text {th }}$ ABM Annual Congress, Rio de Janeiro, Brazil, 2003, p.887-896. [24] JADOON, A.K. Employing reactive synthesis for metal to ceramic joining for high temperature applications. J. Mater. Sci., v.39, p.593-604, 2004.

[25] OKAMOTO, H. Cu-Ti (Cooper-Titanium) J. Phase Equilibria, v.26, n.3, p.549-550, 2002. 